
\title{
環状オリコ糖の応用研究 分子材料
}

\author{
伊藤耕三 (いとうこうぞう) \\ 東京大学大学院 新領域創成科学研究科教授
}

\section{1. はじめに}

シクロデキストリン $(\mathrm{CD})$ は, 食料品や医薬品などの 広い範囲で現在利用されている環状オリゴ糖であり， $\alpha$-, $\beta-, \gamma-\mathrm{CD}$ の 3 種類が現在のところ市販されている。それ ぞれは, グルコースの $6,7,8$ 量体であり, 内径が 0.44 , $0.58,0.74 \mathrm{~nm}$ となっている ${ }^{1.22}$ 。他の環状分子と比べて CD は高純度品を低価格で大量に手に入れることが可能であ り，また水酸基が多数付いているため様々な官能基を容易 に修飾できる。CD は内部が疎水性，外部が親水性である ため, 水中で様々な疎水性低分子を内部に取り込久包接錯 体を形成することが知られていた。1990年に Harada と Kamachi $^{3}$ は， $\alpha-C D$ とポリエチレングリコール (PEG) を 水溶液中で混合したところ自己組織的に多数の $\alpha-\mathrm{CD}$ と PEG が包接錯体を形成することを世界で初めて発見し, これを疑似ポリロタキサンと名付けた。続けて Harada ら は，1992 年に疑似ポリロタキサンの両末端を大きな分子 で封止して $\alpha-C D$ が PEG から抜けないようにすることに 成功し, ポリロタキサンの合成を報告した。この新しい超 分子構造体は, その構造自身が興味深く報告当初から大き な注目を集めているだけでなく，機能性高分子材料を開発 する上での基本的な構成要素としてきわめて重要であり, 現在も盛んに研究が行われている ${ }^{5-7}$ 。

筆者ら ${ }^{81}$ は， 2000 年ころにポリロタキサン構造を利用し て, 図1のような従来とは全く異なる架橋高分子材料を合 成することに成功した。具体的には, 高分子量の PEG を 用いて $\alpha-C D$ がすかすに入ったポリロタキサンを合成 し, 次に異なるポリロタキサン上の $\alpha-\mathrm{CD}$ を化学的に架橋 することで，8の字状の架橋点が自由に動く高分子材料を 世界で初めて作成し，これを環動高分子材料 (Slide-Ring Materials) と名付けた。環動高分子材料では, 環状分子が 化学架橋して 8 の字になった架橋点によりネットワークが 形成されているために, 架橋点が自由に動き, 従来の架橋 点が固定した高分子材料とは本質的に異なる構造と物性を 示す。このような架橋点が自由に動く高分子材料は, 1999 年に de Gennes が sliding gel ${ }^{9}$ と名付けて理論的に考察して いるのみで, 概念としても新しく, 絡み合い効果を理論的 に扱ったスリップリンクモデルを具現化した材料とみなさ れている(10)。ちなに, 日米中欧で物質に限定されない基 本特許が成立済みである。1 839 年のグッドイヤーによる 化学架橋の発見以来, 架橋高分子材料については, 架橋点 が固定していることを前提としてこれまでに実験・理論の 両面で膨大な研究が行なわれてきたが，2000 年になって
架橋点が自由に動く材料が初めて登場し, 架橋高分子材料 に関するこれまでの常識が次々と塗り替えられつつある。 本稿では, 環動高分子材料についての基礎と応用について 紹介する。

\section{2. 環動高分子材料の調製}

環動高分子材料の原料としては, 軸分子に PEG, 環状 分子に $\alpha-\mathrm{CD}$, キャッピング分子としてアダマンタンを用 いたポリロタキサンが, 現在のところ収率などの点で最も 優れており, 量産化が進んでいる。環動高分子材料の特性 を発揮させるためには CD 環が長い距離を動ける方がよい ので, 軸分子はなるべく長く, また包接する $\mathrm{CD}$ の数は比 較的少ない方が好ましい。一例として分子量 35,000 程度 の PEG を軸とし，90〜100 個の CD で包接した試料"11など がよく用いられるが，他にも様々な合成例が報告されてい る。また, ポリロタキサン中の CD の数の制御もある程度 可能であり, ポリロタキサンおよび環動高分子材料の構造 や物性は, $\mathrm{CD}$ の包接率によって大きく変化することが分 かっている。

このようにして得られた PEG/CD のポリロタキサンは $\mathrm{CD}$ 間の強い分子内 ·分子間水素結合のため, 水や大半の 有機溶媒には溶解しない。ポリロタキサンの良溶媒として はこれまでに, DMSO, $\mathrm{NaOH}$ 水溶液, Li 塩を含む DMAc や DMF, 環状アミンオキシド, $\mathrm{Ca}(\mathrm{SCN})_{2}$ 水溶液, イオン 液体などの特殊な溶媒が報告されている タキサンの溶解性の問題は, $\mathrm{CD}$ の修飾によって劇的に改 善され, ポリロタキサン誘導体では水やアセトン, トルエ ン, クロロホルム, 酢酸ブチルなどへの溶解も可能である (難溶性であるセルロースが修飾によって有機溶媒や水に 可溶になるのと同様)。ポリロタキサンの架橋には，未修 飾の場合には水酸基どうしの架橋剤, 誘導体の場合にはそ れ以外の架橋剂やあるいは光なども利用できる。一方，環 動高分子材料の軸高分子としては, PEG 以外の様々な高 分子が利用可能である。実際に我々は, 軸高分子にポリシ ロキサンあるいはポリブタジエンと $\gamma-\mathrm{CD}$ を用いた環動高 分子材料や, PEG と PPG のブロックコポリマーと $\beta-C D$ を用いた環動高分子材料の合成に成功している ${ }^{14)}$ 。

低包接率のポリロタキサンでは，CD は軸分子にそって 移動したり軸分子の周りを回転したりできると考えられて いる。このような性質を特に環動性と呼んでいる。環動高 分子材料は CD の環動性により架橋点が自由に動くため に, 従来の架橋点が固定されたエラストマーやゲルとは大 


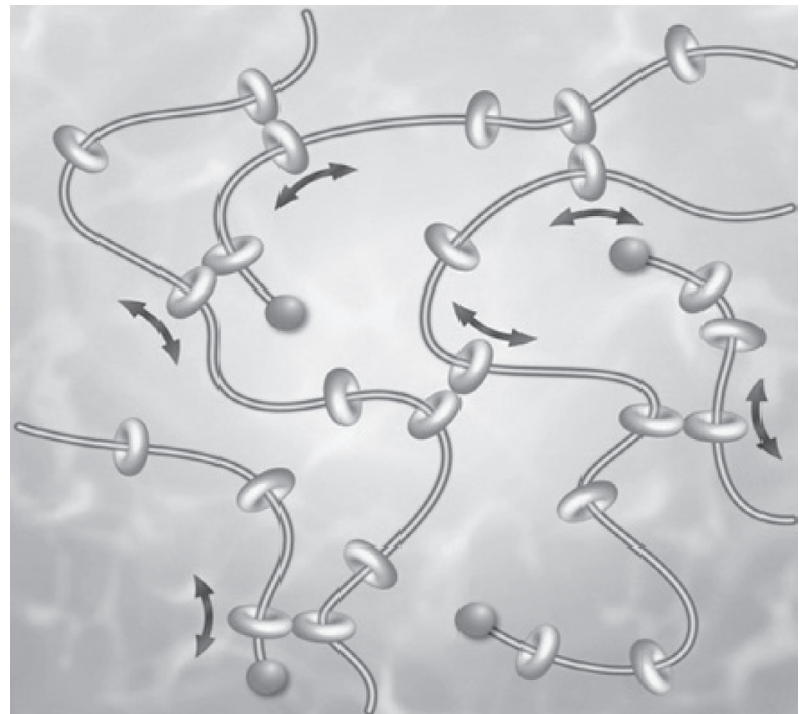

図 1. 環動高分子の模式図

架橋点が固定されていないため，自由に動くことができる。

きく異なる特性を示す。たとえば，環動ゲルは乾燥重量に 対し最大 24,000 倍の膨潤率 (純水膨潤時), 元長に対して 24 倍の伸長率を示す。またゲルとして 80〜90\%の溶媒 (水)を含みながらゴムのように伸び縮みする，いわゆる エラストマー様の引張り特性を示す。さらに，血管や皮膚 などの生体組織と同様の $\mathrm{J}$ 字型の応力伸長特性を示すこと から，生体代替材料としての応用が期待されている ${ }^{15,16}$ 。

\section{3. 環動高分子の力学特性}

もし架橋点が本当に自由に動き，高分子が架橋点を十分 に速く通り抜けることができると，外力がかかっても高分 子の形態は常に等方的になってしまうので，いわゆる高分 子の形態変化に基づくエントロピー弾性が発生しないこと になる。実際に, 環動高分子材料のヤング率は架橋密度に 比例せず，通常の架橋が固定された高分子材料いわゆるゴ ムに比べてはるかに小さいことが知られている。それで は，環動高分子材料のヤング率は何によって決まっている のであろうか。

図 2 は，環動高分子を横に伸長したときの模式図であ る。高分子が環状架橋点を自由に通り抜けることができる のに対して，架橋点間に存在する架橋されていない環状分 子は架橋点を通り抜けることができない。その結果, 自由 な環状分子の分布が不均一になってエントロピーが減少す る。これが，環動高分子における新たなエントロピー弾性 を生み出すことになる。これを, 従来の高分子の形態エン トロピーの減少に基づくエントロピー弾性, すなわちゴム 弾性と区別してスライディング弾性と呼んでいる ${ }^{17)}$

最近の中性子スピンエコーの測定結果によれば，自由な 環状分子のスライディング運動 (スライディングモード) は，高分子セグメントのミクロブラウン運動に比べ一般に 遅いことが分かっている。すると，環動高分子材料のダイ ナミクスは図 3 のようになることが予想される ${ }^{17) 。 す な わ ~}$

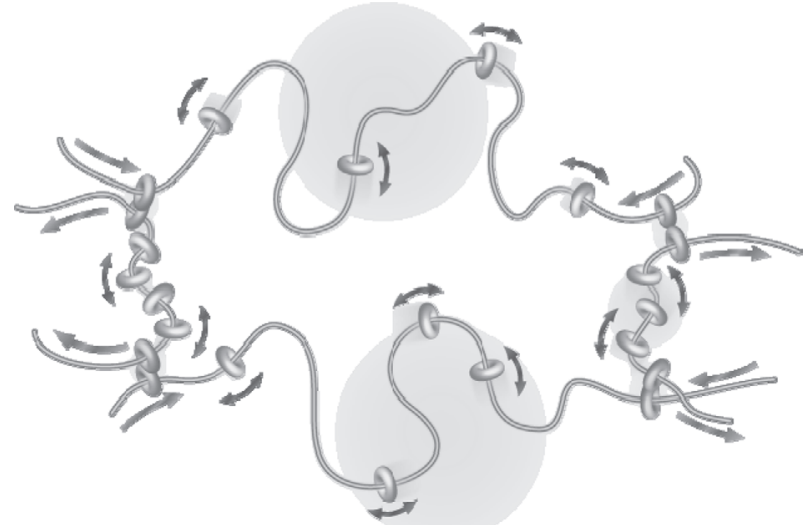

図 2. 環動高分子を横に伸長したときの模式図

滑車効果によって高分子の形態が緩和すると，代わりに架橋 されていない自由な環状分子の分布が不均一になり，スライ ディング弾性と呼ばれる新しいエントロピー弾性を生み出す。

ち，低温・高周波では高分子のミクロブラウン運動と環状 分子のスライディング運動はともに凍結しており，ガラス 状態を示す。温度の上昇あるいは周波数の低下に伴い，先 に動き出すのは高分子のミクロブラウン運動であり，ガラ ス転移を経ていわゆるゴム弾性が現れる (ゴム状態)。こ のとき環状分子のスライディング運動はまだ凍結したまま であり，高分子は架橋点をすり抜けることができない。す なわち，通常のゴムや化学ゲルと同様に，架橋点は固定さ れた状態にある。さらに温度が上がるか周波数が下がる と，今度は環状分子が動き出すとともに，高分子が架橋点 を自由にすりぬけるようになり，ゴム弾性が消失して，ス ライディング運動によるスライディング弾性が現れる (ス ライディング状態)。このようにゴム弾性からスライディ ング弾性に変化することを，スライデイング転移と呼ぶこ とにする。スライディング転移やスライディング状態の存 在は, 環動高分子材料の最も重要な特徴であると考えてい る。

最近我々は，実際にいくつかの軸高分子の異なる環動高 分子材料でスライディング転移の観測に成功している ${ }^{18)}$ 。 また，簡単な理論モデルに基づいてスライディング弾性を 計算して求めたところ, 弾性率は, 環状分子の包接率に比 例するとともに, 架橋密度の $1 / 3$ 乗に比例するという結果 が得られた。もし包接率が高く，スライデイング弾性がゴ ム弾性より大きい場合には，スライディング領域にあった としても通常のゴムと同様に高分子の形態が変形し，スラ イディング弾性は見えなくなるはずである。実際に，その ような実験結果も得られている。

\section{4. 環動ゲルの物性}

化学ゲルを溶媒中で一軸伸長すると，高分子の形態に異 方性が生じてエントロピーが減少するため，異方性を緩和 するために伸長と垂直方向にゲルが膨潤する。これを伸長 誘起膨潤特性と呼んでいる。ゲルの膨潤特性を記述する Flory-Rhener モデルによれば，伸長誘起膨潤におけるポア 


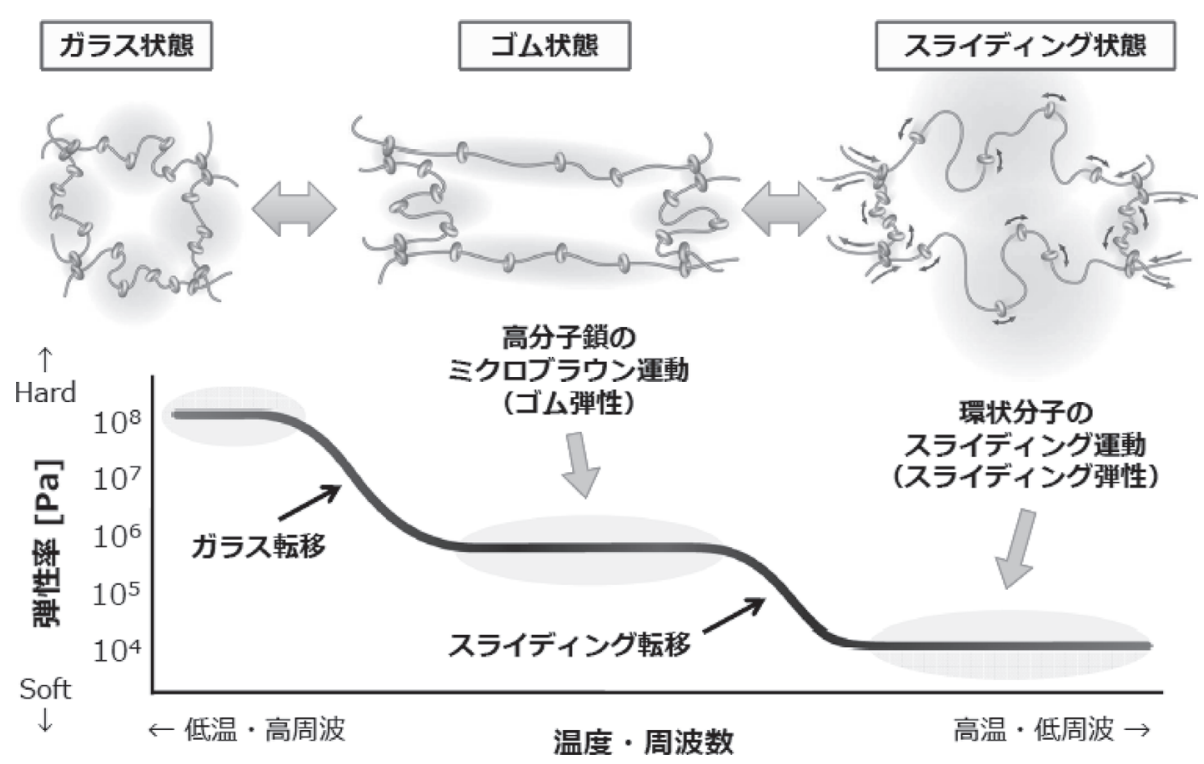

図 3. 環動高分子のダイナミクス

通常のアモルファス高分子がガラス状態とゴム状態の 2 状態を示すのに対して，環動高 分子にはそれ以外にスライディング状態という新しい状態が存在する。

ソン比は伸長率にほとんど依存せずに一定になる。これ は，実験結果ときわめてよく一致しており，Flory-Rhener 理論の妥当性を見事に示している。しかし，環動ゲルの伸 長誘起膨潤におけるポアソン比は，特に低伸長領域で伸長 率に強く依存し, Flory-Rhener 理論から大きく外れる結果 となっている ${ }^{19}$ 。これは，架橋点が動いていることによっ て定性的に説明することが可能であり，架橋点が実際に動 いていることをマクロに示した実験結果になっている。

外部環境の変化に応じて可逆的に物性を変化させること のできる高分子材料は，基礎と応用の両見地から強く関心 が持たれている。もし環動ゲルの滑車効果が外部刺激に よって自由自在に制御できれば，ゲルの力学特性が外部刺 激によって劇的に変化し，柔らかく良く伸びるゲルが突然 硬く伸びなくなる，あるいはその逆が起こり得る。

ポリロタキサンをアルキル基等で化学修飾すると，低温 領域で透明な溶液が，高温領域で転移的かつ可逆的に白濁 したゲルに変化することがわかった20.21。 また 8 の字架橋 点が電荷を持ったイオン性環動ゲルでは，イオン環境の変 化によって同様の現象が観察されている。力学測定や放射 光を用いた小角 X 線散乱測定から, この現象は, 温度上 昇に伴い疎水性相互作用により架橋点の凝集が起こり，滑 車効果が抑制されたためであることが明らかになった222。 このとき, 応力伸長特性が $\mathrm{J}$ 字型から $\mathrm{S}$ 字型に大きく変化 することも報告されている。すなわち，環動ゲル独特の自 由度であるナノスケールの環状分子 (滑車) の運動性を外 部刺激を用いて制御することが可能であり，これによりマ クロな力学物性が実際に大きく変化することがわかった。

温度応答性環動ゲルで，温度上昇に伴う凝集力を制御す ると, 体温付近 $\left(37^{\circ} \mathrm{C}\right)$ で数十秒の間に熱可逆的な転移を 示すゲルが作成できる。すなわち，室温において透明で膨 潤している環動ゲルが，皮膚に当てるとすぐに白濁と収縮 を示すことになる。これまでの同様の温度応答性ゲル材料
に比べ，環動ゲルでは白濁から透明状態へ戻るのがきわめ て速いことが特徴である。これは，環動ゲルの場合には動 く架橋点の凝集により転移が起こるという機構の違いによ るものと考えている。このような新規機能性ゲル材料は, 医療への応用展開が期待される。

さらに，環動ゲルのシクロデキストリン環の水酸基に光 応答性アゾベンゼンを導入し，さらに環動ゲルの架橋部位 にアゾベンゼンを導入することによって，膨潤性を光で制 御可能な光応答性環動ゲルが作成された ${ }^{23}$ 。その挙動は一 旦大きく咭潤した後に収縮が抒き平衡状態に達するとい う，環動ゲル特有のオーバーシュート挙動を示した。紫外 光㧍よび可視光照射によって可逆的に膨潤収縮が誘起さ れ，大きいものでは $100 \%$ 程度の体積変化が観測された。 これはアゾベンゼン系光応答ゲルの体積変化としては従来 に無い大きな応答であり，大きな変形が可能な環動ゲルの 特徵が反映されたものと考えている。

\section{5. 環動エラストマーの物性}

ポリロタキサンにポリカブロラクトンなどをグラフト し，他の高分子をブレンドして架橋すると，図４に示すよ うにゴムのような無溶媒の材料すなわちエラストマーを作 成することができる24)。一般に環動エラストマーは，弾性 率 (ゴム硬度) と圧縮永久歪がともに小さいという特徴が ある。また環動エラストマーでは，振動の吸収を非常に広 い周波数带域にわたって大きくすることが可能であり，実 に 5 桁以上にわたり 1 以上の損失正接 (複素弾性率の虚部 と実部の比: 力学的エネルギーの損失の程度を表し, 0.1 以上であれば振動吸収材として認められている) が実現で きる。これは，振動と音響を 1 つの材料で同時に吸収でき ることを意味しており，振動吸収材料としての応用が注目 を集め始めている。その他に環動エラストマーは，きわめ 


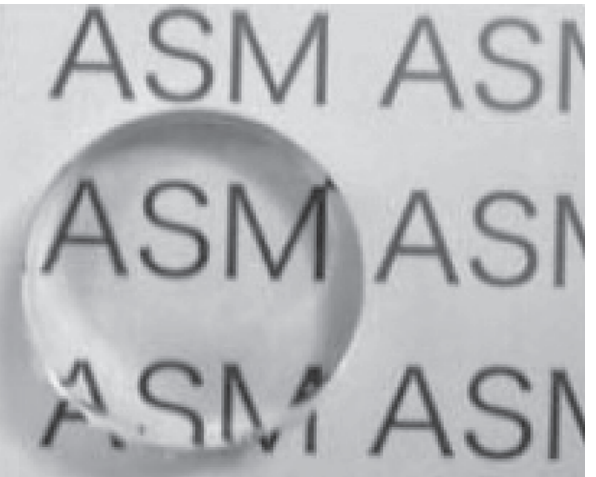

図 4. 環動エラストマーの写真 (アドバンスト・ソフトマテリ アルズ株式会社のホームページより) 透明性が高く，振 動と音響を同時に吸収できる。

て高い透明性を示す。環動エラストマーが，きわめて低い 永久歪や透明性を示すのは，環状分子や軸高分子のスライ ディング運動が常に材料の均一性を保つためであると解釈 している。

一方環動エラストマーは，無機フィラーを大量に分散し ても，ゴムのように弾性率やヒステリシスが著しく大きく ならないという特徴も示す。したがって，無機フィラーの 分散剤として有効であり, 高熱伝導性, 高導電性あるいは 高誘電性エラストマーへの応用が期待されている。たとえ ば，高誘電性環動エラストマーを用いた軽量・高出力・低 電圧駆動の誘電アクチュエータの開発が進んでいる。さら に，環動エラストマーは塗膜として用いると，顕著な耐傷 特性や耐剥がれ性を示す。自動車, 携帯電話, コンピュー 夕などのコーティングへの応用が盛んに検討されており， 携帯電話ではすでに実用化もされている。最後に，環動高 分子の塗膜への応用例を紹介する。

\section{6. 環動高分子の塗膜への応用 ${ }^{25}$}

ポリロタキサンを一般的な塗料に組み込むためには，塗 料溶剂へ溶解させるための疎水性基の導入や，硬化剂と反 応させるための反応性基による修飾を行う必要がある。こ れを硬化剂などと混合することで，塗膜が形成できる。通 常のクリヤー塗膜 (以下，通常塗膜) は，高分子どうしを 化学的に架橋するなど，いわば高分子どうしを「固定」す ることによって強度を出していた。しかし，それによって 逆に伸縮性が失われるという欠点があった。これに対し て，ポリロタキサンを組み込んだクリヤー塗膜 (以下, SRM 塗膜) は，ポリロタキサンと硬化剤が化学反応によ り架橋するが，「滑車効果」により架橋点が自由に動ける。 そのため, 通常塗膜には見られない優れた特性を発現する。

塗膜に先端が鋭い針を用いて傷を付け，時間経過後の傷 が復元する様子を観察すると, 時間経過後も通常塗膜に付 けた傷はまったく復元しないのに対して，SRM 塗膜の場 合には，時間経過後には塗膜の傷が復元している様子が確 認された (復元時間や復元の程度などは, 塗装仕様, クリ ヤーコートの膜厚，傷の深さや周囲の環境等に影響を受け
て変化する)。通常塗膜は，SRM 塗膜に比べて表面硬度は 高いが，伸縮性が格段に低い。そのため，傷や衝撃が加わ ると，その周囲には，縦横無尽に亀裂が入り，そこから剥 がれが広がっていくと推測される。しかし，SRM 塗膜は 「滑車効果」により架橋点が自由に動けるため，たとえ傷 が付いても，そこから周囲に亀裂が入らず，塗膜の剥がれ が広がることがないと考えられる。

\section{7. おわりに}

1839 年のグッドイヤーによる高分子の化学架橋の発見 以来，架橋点は高分子に固定されていることが常識であっ た。ところが，2000年になって初めて架橋点が自由に動 く環動高分子材料が発見され，その後，架橋点の自由な動 き特有の物性や構造が明らかになってきた。これらの物性 は滑車効果と呼ばれ，架橋点の自由な動きが高分子鎖に働 く張力や架橋点分布の不均一性を緩和するためであると考 えられている。また，スライディング弾性やスライディン グ転移など，架橋されていない環状分子の配置エントロ ピーが環動高分子の力学物性に重要な役割を果たしている ことが明らかになりつつある。環動ゲルの発見以来，様々 な測定手段を用いて架橋点の自由な動きや滑車効果が検証 されてきた。たとえば，力学特性や，伸長下の中性子ある いはX 線を用いた小角散乱，準弾性光散乱などを用いて， 環動ゲルが通常の化学ゲルとは大きく異なる特性を示すこ とが次々に明らかになり，現在では滑車効果の存在を支持 する数多くの測定結果が得られている。

環動高分子材料は滑車効果とスライディング弾性によ り，従来の架橋点が固定された高分子材料とは異なる力学 特性と構造を示す。このような特徴は，程度の差はあるも のの，ゲルだけに限らず液体を含まないエラストマーにも 及んでいる。その結果，ソフトコンタクトレンズなどのバ イオマテリアル分野だけでなく，塗料や振動吸収材など工 業材料の分野でも実用化に向けた研究開発が進んでいる。 環動高分子が示す様々な物性の中には，我々の予想を超え るもの，まだ十分に説明できていないものも少なくない。 今後，環動高分子の応用展開が急速に進む中で，基礎的に も高分子科学におけるこの新規分野をさらに発展させてい きたいと考えている。

\section{文献}

1 ) J. Szejtli and T. Osa, eds.: Comprehensive supramolecular chemistry Vol. 3: Cyclodextrins, Pergamon, Elsevier, Oxford, pp. 1-714 (1996).

2 ) H. Dodziuk, ed.: Cyclodextrins and Their Complexes: Chemistry, Analytical Methods, Applications, Wiley-VCH, New York, pp. 1-507 (2006).

3 ) A. Harada and M. Kamachi: Complex Formation between Poly (ethylene glycol) and $\alpha$-Cyclodextrin. Macromolecules, 23, 2821-2823 (1990)

4 ) A. Harada, J. Li and M. Kamachi: The Molecular Necklace: a rotaxane containg many threaded $\alpha$-cyclodextrins. Nature, 356, 325-327 (1992). 
5 ) A. Harada, A. Hashidzume, H. Yamaguchi, and Y. Takashima: Polymeric rotaxanes. Chem. Rev., 109, 5974-6023 (2009).

6 ) J. Araki and K. Ito: Recent Advances in the preparation of cyclodextrin-based polyrotaxanes and their applications to soft materials. Soft Matter, 3, 1456-1473 (2007).

7 ) S. Loethen, J.-M. Kim and D.H. Thompson: Biomedical Applications of Cyclodextrin-Based Polyrotaxanes. J. Macromol. Sci. C-Polym. Rev., 47, 383-418 (2007).

8 ) Y. Okumura and K. Ito: The polyrotaxane gel: A topological gel by figure-of-eight cross-links. Adv. Mater., 13, 485-487 (2001).

9 ) P.G. de Gennes: Sliding gels. Physica A, 271, 231-237 (1999).

10) S. Granick and M. Rubinstein: Polymers: A multitude of macromolecules. Nat. Mater., 3, 586-587 (2003)

11) J. Araki, C. Zhao and K. Ito: Efficient Production of Polyrotaxanes from -Cyclodextrin and Poly(ethylene glycol). Macromolecules, 38, 7524-7527 (2005)

12）荒木 潤，伊藤耕三：ポリロタキサンおよびポリロタキサ ン誘導体の合成と性質。色材協会誌，79，290-295 (2006).

13）荒木 潤，伊藤耕三：シクロデキストリンの応用技術，寺 尾啓二・小宮山真編，シーエムシー出版，東京，pp. 315329 (2008)

14) K. Kato and K. Ito: A versatile synthesis of diverse polyrotaxanes with a dual role of cyclodextrin as both the cyclic and capping. component. Macromolecules, 43, 8799-8804 (2010).

15) K. Ito: Novel cross-linking concept of polymer network: Synthesis, structure, and properties of slide-ring gels with freely movable junctions. Polym. J., 39, 488-499 (2007).

16) K. Ito: Slide-ring materials using topological supramolecular architecture. Curr. Opin. Solid State Mater. Sci., 14, 28-34 (2010)

17) K. Ito: Novel entropic elasticity of polymeric materials: why is slide-ring gel so soft? Polym. J., in press (2011).

18) K. Kato and K. Ito: Dynamic transition between rubber and sliding state attributed to slidable cross-links. Soft Matter, 7, 8737-8740 (2011).

19) N. Murata, A. Konda, K. Urayama, T. Takigawa, M. Kidowaki and K. Ito: Anomaly In stretching-induced swelling of slidering gels with movable cross-links. Macromolecules, 42, 84858491 (2009).

20) M. Kidowaki, C. Zhao, T. Kataoka and K. Ito: Thermoreversible sol-gel transition of an aqueous solution of polyrotaxane composed of highly methylated $\alpha$-cyclodextrin and polyethylene glycol. Chem. Commun., 4102-4103 (2006).

21) T. Kataoka, M. Kidowak, C. Zhao, H. Minamikawa, T. Shimizu, and K. Ito: Local and network structure of thermoreversible polyrotaxane hydrogels based on poly(ethylene glycol) and methylated $\alpha$-cyclodextrins. J. Phys. Chem., B, 110, 24377-24383 (2006).

22) Y. Shinohara, K. Kayashima, Y. Okumura, C. Zhao, K. Ito, and Y. Amemiya: Small-angle X-ray scattering study of the pulley effect of slide-ring gels. Macromolecules, 39, 73867391 (2006).

23) T. Sakai, H. Murayama, S. Nagano, Y. Takeoka, M. Kidowaki, K. Ito, and T. Seki: Photoresponsive ring-slide gels. Adv. Mater, 19, 2023-2025 (2007).

24) J. Araki, T. Kataoka, and K. Ito: Preparation of a "sliding graft copolymer", an organic solvent-soluble polyrotaxane containing mobile side chains, and its application for a crosslinked elastomeric supramolecular film. Soft Matter, 4, 245-249 (2008).

25）クリスチャン・ルスリム, 田畑智: 研究開発情報 ポリ ロタキサンの特徵と塗料への応用ポリロタキサンの特徵と 塗料への応用.月刊ファインケミカル，39(9)，53-60 (2010). 